\title{
Effect of semen washing methods on diminishing the transmission of viral infections in artificial reproductive technology
}

\author{
Fereshteh Aliakbari $^{\circledR}$, Neda Taghizabet ${ }^{1}{ }^{\circledR}$, Fatemeh Rezaei-Tazangi ${ }^{\circledR}$, Ebrahim Kharazi Nejad ${ }^{3^{*}}$ \\ 'Men's Health and Reproductive Health Research Center, Shahid Beheshti University of Medical Sciences, Tehran, Iran \\ ${ }^{2}$ Department of Anatomical Sciences, Faculty of Medicine, Ahvaz Jundishapur University of Medical Sciences, Ahvaz, Iran \\ ${ }^{3}$ Abadan School of Medical Sciences, Abadan, Iran
}

\section{Correspondence to:}

Ebrahim Kharazi Nejad, Email: kharazi.ebrahim@gmail.com

Received: 20 Feb. 2021 Accepted: 6 June 2021 ePublished: 29 Aug. 2021

Keywords: Semen washing, Assisted reproduction, Infertility, Virus transmission

\begin{abstract}
Seminal infections were considered to be an etiologic factor of male infertility. Semen washing is used as an appropriate technique in artificial reproductive technology (ART) for serodiscordant couples when the partner of male is contaminated. The aim of this study was to investigate the role of semen washing methods in reducing the transmission of viral infections in ART. In this narrative review we investigated accessible information from Google Scholar, PubMed, Scopus, Web of Science, IranMedex, Irandoc, Magiran, SID, MEDLIB and Scientific Information Database until 2019. The MeSH terms of semen washing, HIV, assisted reproduction, serodiscordant, and virus transmission were used. According to the search strategy, 89 articles were discovered. After checking the titles, abstracts and manuscripts, a collection of 45 papers were chosen pursuant to the suitability indexes. The studies were performed around different categories of semen washing (swim up, density gradient) in serodiscordant couples. Some studies highlighted that semen washings can completely prevent viral transmission, but a few do not believe this claim. However, scientific researchers have revealed that sperm washing may diminish the possibility of infection in serodiscordant couples where the male partner is infected. Swim up in combination with density gradient is a suitable method to diminish the transmission of infections.
\end{abstract}

\section{Introduction}

Citation: Aliakbari F, Taghizabet N, RezaeiTazangi F, Kharazi Nejad E. Effect of semen washing methods on diminishing the transmission of viral infections in artificial reproductive technology. J Prev Epidemiol. 2021;6(2):e33. doi: 10.34172/jpe.2021.33
All of the infertility factors in men have not been identified yet and more comprehensive studies are required (1). Approximately, 15\% of male infertility is related to genital and urinary tract infectious agents $(2,3)$. Since $30 \%$ of infertility factors are idiopathic, one of these unknown factors can be considered as viral contamination. Researchers have sought to identify all infectious and noninfectious agents comprehensively (4). Viruses play an important role in the possible factors affecting genital function; of course, further studies are required to prove these findings (5). Such as HIV disease, chronic viral infection of the urogenital tract can reduce fertility (6). Previous studies revealed that hepatitis $B$ virus and hepatitis $C$ virus (HCV) affect fertility (7). Semen infections can impair sperm parameters, especially reduce sperm movements; moreover, these changes were seen in most of these infections. Meanwhile, viral infections of semen can increase the incidence of sperm aneuploidy and DNA segmentation (5). Sperm washing is one of the effective

\section{Key point}

Viral infections of semen can increase the incidence of sperm aneuploidy and DNA segmentation. Sperm washing is one of the effective procedures to reduce contamination and transmission of infections. Semen washing also reduces the possibility of transfer in HIV-incompatible couples irrespective of viral inhibition in the male partner.

procedures to reduce contamination and transmission of infections. Two common sperm preparation techniques are swim up and density gradient centrifugation that will be explained as follows (8). The main goal of this narrative review was evaluation of the role of sperm washing methods in reduction of viral infections in artificial reproductive technology (ART).

\section{Materials and Methods}

Search was done to extract the basic Persian and English articles. A comprehensive research was conducted on international and Iranian databases including Google Scholar, Scopus, PubMed, ProQuest IranMedex, and Scientific Information Database (SID). All

Copyright (C) 2021 The Author(s); Published by Society of Diabetic Nephropathy Prevention. This is an open-access article distributed under the terms of the Creative Commons Attribution License (http://creativecommons.org/licenses/by/4.0), which permits unrestricted use, distribution, and reproduction in any medium, provided the original work is properly cited. 
related articles comprised the following keywords: semen washing, HIV, assisted reproduction, serodiscordant, virus transmission and were published until 2019. Furthermore, the referral rosters of the retrieved articles were checked to find useful provenance.

\section{Choice indexes}

Initially, we selected the articles by screening titles and abstracts. The analysis of the articles was found eligible for the included criteria: (a) Papers that had some of the keywords outlined in research method in their titles; (b) papers in English or Persian; (c) articles had been indexed in one of the above-hinted databases. The deprived articles: (1) Papers repeated in more than one database were enumerated as one; (2) non-original papers like letter to the editor and short communication were not considered.

\section{Data extraction}

We totally studied each article and recorded the information into a spreadsheet that contained authors, year of publication, sampling, processing method and findings. Some of the articles found focused on the theme of swimming up and density gradient methods in HIV-positive men that were not related to the HIV/ $\mathrm{HCV}$ transmission. We carried out a qualitative analysis according to heterogeneity in the literature.

\section{Results}

Based on the search strategy, 89 articles were studied. After checking the titles, abstracts and manuscripts, sum of 45 papers were chosen in accordance with the suitability criteria. The papers were performed in sperm washing different categories (swim up, density gradient) in serodiscordant couples.

\section{Human immunodeficiency virus (HIV)}

HIV impairs immune cells that fight infections in the body and eliminates them. As a result, the body becomes vulnerable to diseases that were easily cured before (9). HIV affects the majority of people who are of reproductive age (15-45 years). Anti-retroviral treatment is available, causes significant virological suppression and increases the quality of life of the patients (10). It is not satisfying for fertility treatment to HIV-positive patients. This variability is affected by numerous agents such as the type of sexual relationship, genital infection, genetic and immunologic cofactors (11).

Former studies have introduced the attendance of HIV in semen of people. Today infected males are suggested to have children and are wanting to take conduction risks in ART. HIV-positive can decrease sperm parameters through the HIV disease or ART treatment correlated hypogonadism (12). ART programs have had a significant effect on preventing viral transmission (10).

Gilling-Smith et al reported the effect of HIV on sperm parameters and following semen washing. They demonstrated that HIV infection could damage the sperm parameters. Also, they showed that following sperm washing reduced HIV infection (13). The clinics of ART can help HIV-1-infected individuals to imagine their children in Europe and the American Society changing guidelines to allow ART clinics and help HIV-1 contaminated couples in the United States (14). Different fertility clinics used sperm washing techniques when the patient is HIV positive.

Sperm cannot express the receptors of HIV including CD4, CCR5, CXCR4 and a mixture of the density gradient method after swimming up that has been suggested as a method to isolate HIV-free and motile spermatozoa from seminal plasma to prevent infection of female partners (15).

Briat et al suggested that, despite the impression of the washing technique (density gradient), the post-wash HIV test on semen is considered to determine residual positive specimens. They showed five out of 269 (1.86\%) specimens were washed with the density gradient method stayed positive for HIV at the post-wash trial (16).

The frequency of virus detection in semen depends on several factors such as the sensitivity of the method and selection criteria of patients.

Many studies have detected HIV RNA in 62\%-96\% of seminal plasma (17). Finally, the amount of seminal plasma HIV RNA was suggested that is different in different people.

The virus isolation of seminal cells during cultures ranged from 9 to $55 \%$. And, 4 to $65 \%$ of seminal cells were detected by the provirus form of HIV by the PCR technique. PCR is a susceptible technique for the detection of virus cells (18). The sensibility for RNA tracing was 500- 1000 RNA copies/mL in seminal plasma; also, it was 50500 DNA copies/106 cells for DNA detection (18). The list of studies has been prepared in Table 1.

\section{Herpesviruses}

Herpesviruses cause a high level of infection in human population. The primary infection of these viruses is mainly without symptoms and remains hidden at some points in the body. The isolation of herpes viruses has been reported in a variety of body samples such as blood, eye, urine and CSF (19).

Types of viral DNA from the herpes family including HSV 1 and HSV2 in semen of infertile people without clinical signs have been detected. HHV-6A/B is the most prevalent herpesvirus, in semen of healthy men. The virus seems to be conducted dependent on the acrosomal region of sperm. Therefore, HHV-6A/B was transportable to the uterus by subjugating the acrosome of sperm (20).

Especially HSV has widely been studied and shown to be able to produce fetal and infantile anomalies (21). According to the data from the United States, there are at least 50 million people with genital herpes and 500,000 new cases of newborns per year (22). Looker et al estimated 
Table 1. List of studies conducted in the field of semen washing

\begin{tabular}{|c|c|c|c|c|c|c|}
\hline Author & Location & Patients & Semen washing & RNA extraction & Result & ART \\
\hline Politch et al ${ }^{14}$ & Boston & $\begin{array}{l}\text { HIV-1 seronegative } \\
\text { men }\end{array}$ & Gradient/swim-up & RT-PCR & Negative & - \\
\hline Nicopoullos et al ${ }^{56}$ & UK & $\begin{array}{l}\text { Obstructive } \\
\text { azoospermia }\end{array}$ & Swim-up & $\begin{array}{l}\text { Sequence amplification } \\
\text { testing }\end{array}$ & Negative & ICSI \\
\hline Bujan et al ${ }^{66}$ & France & $\begin{array}{l}\text { HIV-1-serodiscordant } \\
\text { couples }\end{array}$ & Gradient density & PCR & Negative & IUI \\
\hline Bourlet et al ${ }^{67}$ & France & HCV-infected male & Gradient & Quantitative PCR & Positive & - \\
\hline Ohl et al $^{68}$ & France & HIV- infected male & Density gradient/swim-up & PCR & $\begin{array}{l}\text { Negative } \\
(98 \%)\end{array}$ & ICSI \\
\hline Halfon et al ${ }^{69}$ & France & HCV-infected male & Density gradient & PCR & Positive & - \\
\hline Bujan et $\mathrm{al}^{57}$ & France & Azoospermic & Density gradient & Sequence amplification & Negative & ICSI \\
\hline Bostan et $\mathrm{al}^{70}$ & Belgium & Oligospermia & Single sperm washing & Nested RT-PCR & Negative & ICSI \\
\hline Giles et $\mathrm{a}^{40}$ & Australia & $\begin{array}{l}\text { HIV-serodiscordant } \\
\text { couples }\end{array}$ & Single-arm open trial & PCR, RT-PCR & Negative & $\begin{array}{l}\text { IUI, IVF } \\
\text { ICSI }\end{array}$ \\
\hline Foresta et $\mathrm{al}^{37}$ & Italy & HPV-infected male & Density/swim-up & In-situ hybridization & Positive & - \\
\hline Lambert-Niclot et al ${ }^{71}$ & France & HIV-1 infected men & Density gradient & PCR & $\begin{array}{l}\text { Negative (not } \\
\text { all) }\end{array}$ & - \\
\hline Zamora et al ${ }^{66}$ & UK & HIV-infected male & Triple-density gradient & RT-PCR & $\begin{array}{l}98.4 \% \\
\text { negative }\end{array}$ & ICSI \\
\hline Safier et $\mathrm{al}^{8}$ & New York & HIV- infected male & Density/swim-up & - & Negative & IUI \\
\hline
\end{tabular}

that 417 million people have been infected worldwide with a range of 15-49 and also 2.9 million new cases of HSV2 infection in 2012 (23).

Contrary to the clinical importance of perceptions, the impression of herpesvirus in infertility with male causes remains uncertain (23).

\section{Hepatitis C virus (HCV)}

Sexual transfer of HCV is an important issue; nevertheless, the effectiveness of this transfer in the progress of $\mathrm{HCV}$ is undetermined. Previous researches consider an accelerating prevalence of $\mathrm{HCV}$ in $\mathrm{HIV}$-1-contaminated men. HCV RNA is retrieved from the semen of HCVcontaminated men almost $10 \%-30 \%$. Nowadays, it is possible for HCV to progress via biological fluids like semen but it can be regulated by proper initial detection in infertility centers (24).

The recent finding reports the attendance of HCV RNA in seminal plasma. The role of semen from men who had chronic

$\mathrm{HCV}$ infection may cause contamination of the female partner. Techniques of HCV RNA quantitation in semen from men with chronic HCV infection. Depend on molecular techniques and types of methods for RNA extraction (25).

Finally, HCV RNA in seminal plasma measurement is allocated for polymerase chain reaction (PCR) techniques (26). Bourlet et al showed that the attendance of HCV
RNA in seminal plasma of men with chronic $\mathrm{HCV}$ infection. HCV infection has a negative impact on the sperm parameters (27).

\section{Human papillomaviruses (HPVs)}

HPVs are with high incidence among men aged 18-40 years. They have a different type but the mucosal type infects the genital area. Most HPV types are transferred sexually and consist of the most common factors (28).

Other research has shown that HPVDNA and RNA are found in various compartments of male genitalia composing the urethra, epididymis, testis and penis shaft.

It is believed that the attendance of glycoproteins and other soluble agents on the spermatozoon level are involved in the binding and interaction of HPV to sperm. Recent research indicates that L1 HPV capsid protein and glycosaminoglycan syndecan-1accumulate on the sperm head (29).

On the other hand, the results of yet another study showed that if DNA type 18 is exposed to the p53 gene, it causes exome 5 fragmentation in this gene. In contrast, HPV type 16 had a similar effect on exon 8 . So different types of HPV have different effects on different parts of the genome (30).

DNA HPV exists in $10 \%$ of semen samples and the virus can be concentrate in sperm cells (31). HPV topic is an important subject to clinicians and researchers because the attendance of HPV DNA in the seminal fluid can 
cause poor sperm quality as reducing sperm motility. Furthermore, the attendance of HPV has been detected in semen since this infection is generally suggested transitory in males and without harmful clinical outcomes; Also, the investigation of its impacts on sperm parameters and male fertility was inadequate (32). HPV can attach to spermatozoa and can be conducted to fertilized oocytes. Viral finding in blastocysts and trophoblastic cells is correlated with damaged embryo growth and negligible pregnancy consequence (33).

To prevail the tenacity of HPV DNA attachment to sperm and to decrease the possibility of HPV infection during ART, an improved swim-up with the addition of heparinase III has recently been suggested. This technique was able to perfectly remove HPV DNA from semen and did not reveal any remarkable change of sperm quality and DNA integrity $(33,34)$.

Meanwhile, some investigators believed that sperm washing cannot remove HPV from contaminated semen so it can allow viral transmission through ART procedures $(35,36)$.

Foresta et al revealed attendance of HPV-infected sperm in thawed cryovials in specimens obtained from infertile patients. They showed that dangerous types of HPV are correlated with fatal diseases of the reproductive genital tract (37).

\section{Semen washing}

Semen washing is routinely used before in vitro fertilization (IVF), intrauterine insemination (IUI) and intracytoplasmic sperm injection (ICSI) for serodiscordant couples.

It is important to use a semen washing protocol that obtains functional sperm (38).

Conventional techniques are performed for cell separation but they are toxic for sperm (39). Many studies have evaluated the effect of semen washing following the introduction in conjunction with ART on HIV transmission in HIV discordant couples (40). There are many methods for isolating human sperm from seminal plasma involving the swim-up (SUP), self-migration sedimentation, glass wool filtration, magnetic-activated cell sorting and density gradient (DG). The most generally applicated methods in ART therapy are SUP and DG (41). Fertility clinics perform "semen washing" methods before medical treatment.

Finally, semen specimens should be screened for HIV existence and only HIV-free specimen scan be applied for ART (42). PCR-based HIV detection does not consider treatment for HIV serodiscordant couples in some clinics (43).

Successive centrifugation of semen led to sperm dysfunction by release of reactive oxygen species (ROS) by semen leukocytes, although possible risks of viral transmission cannot be ignored completely $(44,45)$. In first study Semprini et al reported that there is no HIV conduction in 29 uninfected female partners by using semen washing for HIV incompatible couples (46). Foresta et al showed that sperm washing procedures seldom remove HPV infection (47).

Infected patients require more attention since HPV can be conducted, as well as have a negative impact on the growth of fetus (47). SUP and DGC are suitable techniques for sperm separation. Sperm is recovered with minimal dysfunction by using these methods (48).

In SUP a layer of special culture medium is placed in the test tube and it is centrifuged; then, the tube is located at an angle of 45 degrees at $37^{\circ} \mathrm{C}$ in the incubator. In this method motile sperm enters the medium while dead and non-moving sperm and debris remain at the bottom of the tube (49).

The mechanism of SUP protocol relies on the potential of the motile sperm to swim toward the culture medium but the immotile sperm remains in the bottom of the plate with other components (50). Mahadevan and Baker described the swim-up method in 1984 (51). Kim et al demonstrated that swim-up methods significantly isolate the motile sperm from the seminal plasma and non-motile cells; moreover, reduce HIV RNA (52). The combination of DG with sperm swim-up has been applicate in infertility centers for years (53).

DGC has commonly been used as part of infertility treatment. In this method, semen is placed in two layers with different gradient percentages. The mechanism of gradient includes centrifuging of semen in a $40 \%-80 \%$ colloidal silica density gradient (39). This method was performed through application of silane-coated colloidal silica particles in suspension $(39,54)$. The mechanism of this method includes separating the white blood cells and free HIV particles from the motile sperm. After washing with sperm washing medium the supernatant motile sperm utilized for the IUI or IVF (55). However, this protocol cannot be performed in acute oligospermia and azoospermia HIV-positive adults because surgical sperm retrieval from the epididymis and testis cannot provide enough sperm for detectable HIV RNA (55).

Previous studies have been reported the application of both techniques of surgical sperm retrieval and sperm washing in azoospermia HIV-positive adults in ICSI cycle $(56,57)$.

\section{Discussion}

Fertility clinics must consider that a sperm separation protocol is efficient and safe (1).

Semen washing removes free HIV particles and numerous white blood cells that may be contaminated with HIV (58). It often includes density gradient for sperm isolation and may be created by a swim-up protocol to delete immotile cells (59).

Processed sperm checked out for ART and performed by testing or HIV-1 RNA or DNA extraction. The virologists could use their special tests or change commercial tests. 
Also, a commercial test is accessible for the observation of HIV-1 in seminal plasma or semen cells and it is currently used in routine use in different centers (60). The sperm can be utilized for medical treatment through IUI, IVF or ICSI techniques if virus is not detected in the sperm after sperm washing (61).

Bujan et al performed a study to evaluate the sensitivity of assays utilized to survey the semen of HIV-infected men before medical treatment and to assess the safety before sperm processing. They suggested these experiments on semen are needed legally before medical treatment from HIV infected men in countries such as France (62). They designed three panels of samples to observe available situations.

Three panels of samples including panel A which detects HIV-1 RNA in seminal plasma, panel B which detects HIV particles that may stay on sperm and panel $\mathrm{C}$ which detects HIV-infected cells remaining between processed sperm. They observed that panel $\mathrm{C}$ was not permitted to evaluate the assay sensitivity because the number of HIV RNA copies/infected cell was unclear.

They highlighted that modality regulation confirmed the requirement for detecting virus as HIV in semen and for normal assessment of their proficiency (62).

Recent studies present the immunity of IUI after semen washing. Semen washing protocols are included gradient density and swim up that are the most important reservoir of virus in semen.

Several studies demonstrate that HIV-1 can contaminate sperm $(63,64)$ whereas others do not believe these findings. PCR, real-time PCR (qPCR) and nucleic acid sequencebased amplification for HIV RNA have considered that $92 \%-99 \%$ of samples of analyzed semen compose no viruses detectable above the limits of the test (65).

According to the studies that have been carried out and various results have been obtained, it seems that further research is needed. Although sperm washing has been utilized as a safe, appropriate method to reduce the possibility of virus as HIV transfer to female partner. Also, sperm washing with ICSI has been utilized as an initial stage of assisted reproduction treatment; meanwhile, this strategy is usually expensive. We studied a systematic review article to investigate sperm washing methods and their role in reducing the transmission of the virus.

\section{Conclusion}

Current findings suggest that the possibility of transfer from an HIV-infected male partner to a healthy female partner is low, if suitable techniques are adopted. Semen washing is a suitable protocol for HIV-incompatible couples in which the male is contaminated. Semen washing reduces the possibility of transfer in HIV-incompatible couples irrespective of viral inhibition in the male partner. Sperm washing with GD seems to be an appropriate technique in HIV serodiscordant couples.

\section{Suggestions for future studies}

This study was conducted in a limited population and more studies are recommended, especially in Iranian societies, by considering limitations.

\section{Authors' contribution}

AF contributed to the design, implementation of the research, and writing the initial draft of the manuscript. TN participated in collection \& analysis of data and development of the structure of the paper. The revision process was entirely made by RTF. KNE contributed to the English editing and approved the final draft of the paper. All authors read and approved the final manuscript.

Conflicts of interest

The authors have no conflict of interest to declare.

\section{Ethical issues}

Ethical issues (including plagiarism, data fabrication, double publication) have been completely observed by the authors.

\section{Funding/Support}

The authors declare that there are no sources of funding.

\section{References}

1. Kharizinejad E, Minaee Zanganeh B, Khanlarkhani N, Mortezaee K, Rastegar T, Baazm M, et al. Role of spermatogonial stem cells extract in transdifferentiation of 5-Aza-2'-deoxycytidine-treated bone marrow mesenchymal stem cells into germ-like cells. Microsc Res Tech. 2016;79:36573. doi: 10.1002/jemt.22639.

2. Khanlarkhani N, Mortezaee K, Amidi F, Kharazinejad E, Beyer C, Baazm M, et al. Role of stromal derived factor-1a (SDF-1a) for spermatogenesis of busulfan-injured rats. Reprod Toxicol. 2017;73:142-8. doi: 10.1016/j.reprotox.2017.08.006.

3. Yao DF, Mills JN. Male infertility: lifestyle factors and holistic, complementary, and alternative therapies. Asian J Androl. 2016;18:410-8. doi: 10.4103/1008-682x.175779.

4. Bracke A, Peeters K, Punjabi U, Hoogewijs D, Dewilde S. A search for molecular mechanisms underlying male idiopathic infertility. Reprod Biomed Online. 2018;36:327-39. doi: 10.1016/j.rbmo.2017.12.005.

5. Jungwirth A, Giwercman A, Tournaye H, Diemer T, Kopa Z, Dohle G, et al. European Association of Urology guidelines on Male Infertility: the 2012 update. Eur Urol. 2012;62:324-32. doi: 10.1016/j.eururo.2012.04.048.

6. Vankerkem P, Manigart Y, Delvigne A, Ameye L, Konopnicki D, Shaw-Jackson C, et al. In vitro fertilization when men, women, or both partners are positive for HIV: a case-control study. Arch Gynecol Obstet. 2017;295:1493-507. doi: 10.1007/s00404017-4374-0.

7. Fode M, Fusco F, Lipshultz L, Weidner W. Sexually transmitted disease and male infertility: a systematic review. Eur Urol Focus. 2016;2:383-93. doi: 10.1016/j.euf.2016.08.002.

8. Safier LZ, Grossman LC, Sauer MV, Douglas NC. Sperm washing with intrauterine insemination and preexposure prophylaxis: an innovative approach to treating HIVserodiscordant couples. Am J Obstet Gynecol. 2017;216:6178. doi: 10.1016/j.ajog.2017.02.038.

9. Cito G, Coccia ME, Fucci R, Picone R, Cocci A, Russo Gl, et al. Influence of male human immunodeficiency virus (HIV) and hepatitis $\mathrm{C}$ virus (HCV) infection on the reproductive outcomes in serodiscordant couples: a case-control study. Andrology. 
2019;7:852-8. doi: 10.1111/andr.12623.

10. Savasi V, Oneta M, Laoreti A, Parisi F, Parrilla B, Duca P, et al. Effects of antiretroviral therapy on sperm DNA integrity of HIV1-infected men. Am J Mens Health. 2018;12:1835-42. doi: 10.1177/1557988318794282.

11. Keogan S, Siegert K, Wigdahl B, Krebs FC. Critical review: immunomodulation by seminal factors and implications for male-to-female HIV-1 transmission. J Acquir Immune Defic Syndr. 2015;69:131-7. doi: 10.1097/qai.0000000000000561.

12. Vernazza PL, Gilliam BL, Flepp M, Dyer JR, Frank AC, Fiscus $\mathrm{SA}$, et al. Effect of antiviral treatment on the shedding of HIV-1 in semen. AIDS. 1997;11:1249-54. doi: 10.1097/00002030199710000-00008.

13. Gilling-Smith C, Nicopoullos JD, Semprini AE, Frodsham LC. HIV and reproductive care-a review of current practice. BJOG. 2006;113:869-78. doi: 10.1111/j.1471-0528.2006.00960.x.

14. Politch JA, Xu C, Tucker L, Anderson DJ. Separation of human immunodeficiency virus type 1 from motile sperm by the double tube gradient method versus other methods. Fertil Steril. 2004;81:440-7. doi: 10.1016/j.fertnstert.2003.06.02

15. Jiménez-Baranda S, Gómez-Moutón C, Rojas A, MartínezPrats L, Mira E, Ana Lacalle $\mathrm{R}$, et al. Filamin-A regulates actin-dependent clustering of HIV receptors. Nat Cell Biol. 2007;9:838-46. doi: 10.1038/ncb1610.

16. Briat A, Dulioust E, Galimand J, Fontaine H, Chaix ML, LeturKönirsch $\mathrm{H}$, etal. Hepatitis $\mathrm{C}$ virus in the semen of men coinfected with HIV-1: prevalence and origin. AIDS. 2005;19:1827-35. doi: 10.1097/01.aids.0000189847.98569.2d.

17. Sheth PM, Kovacs C, Kemal KS, Jones RB, Raboud JM, Pilon R, et al. Persistent HIV RNA shedding in semen despite effective antiretroviral therapy. AIDS. 2009;23:2050-4. doi: 10.1097/ QAD.0b013e3283303e04.

18. Tachet A, Dulioust E, Salmon D, De Almeida M, Rivalland S, Finkielsztejn $\mathrm{L}$, et al. Detection and quantification of HIV-1 in semen: identification of a subpopulation of men at high potential risk of viral sexual transmission. AIDS. 1999;13:82331. doi: 10.1097/00002030-199905070-00012.

19. Bastawecy IM, Zaki AA, Sobhy NM. Ovine herpesvirus 2 infection causes sudden death and abortion in susceptible animals. Life Sci J. 2014;11:957-64. doi: 10.7537/ marslsj111014.148.

20. Kaspersen MD, Larsen PB, Kofod-Olsen E, Fedder J, Bonde J, Höllsberg P. Human herpesvirus-6A/B binds to spermatozoa acrosome and is the most prevalent herpesvirus in semen from sperm donors. PLoS One. 2012;7:e48810. doi: 10.1371/ journal.pone.0048810.

21. Zuckerman RA, Lucchetti A, Whittington WL, Sánchez J, Coombs RW, Magaret A, et al. HSV suppression reduces seminal HIV-1 levels in HIV-1/HSV-2 co-infected men who have sex with men. AIDS. 2009;23:479-83. doi: 10.1097/ QAD.0b013e328326ca62.

22. Kawwass JF, Smith DK, Kissin DM, Haddad LB, Boulet SL, Sunderam S, et al. Strategies for preventing HIV infection among HIV-uninfected women attempting conception with HIV-infected men - United States. MMWR Morb Mortal Wkly Rep. 2017;66:554-7. doi: 10.15585/mmwr.mm6621a2.

23. Looker KJ, Magaret AS, Turner KM, Vickerman P, Gottlieb SL, Newman LM. Global estimates of prevalent and incident herpes simplex virus type 2 infections in 2012. PLoS One. 2015;10:e114989. doi: 10.1371/journal.pone.0114989.

24. Abravanel F, Métivier S, Chauveau M, Péron JM, Izopet J. Transmission of HCV NS5A inhibitor-resistant variants among HIV-infected men who have sex with men. Clin Infect Dis.
2016;63:1271-2. doi: 10.1093/cid/ciw554.

25. Hassan A, Ibrahim A, Fawzy A, Abdel-Hafez M, El-Sherbeny W, Mostafa T. 240 serum-seminal HCV viral load relationship in chronic seropositive patients. J Sex Med. 2017;14:S69-S70. doi: 10.1016/j.jsxm.2016.11.154.

26. Kalu E, Wood R, Vourliotis M, Gilling-Smith C. Fertility needs and funding in couples with blood-borne viral infection. HIV Med. 2010;11:90-3. doi: 10.1111/j.1468-1293.2009.00749.x.

27. Tomás CC, Oliveira E, Sousa D, Uba-Chupel M, Furtado G, Rocha C, et al. Proceedings of the 3rd IPLeiria's International Health Congress: Leiria, Portugal. 6-7 May 2016. BMC Health Serv Res. 2016;16:200. doi: 10.1186/s12913-016-1423-5.

28. Garolla A, Pizzol D, Bertoldo A, Menegazzo M, Barzon L, Foresta C. Sperm viral infection and male infertility: focus on HBV, HCV, HIV, HPV, HSV, HCMV, and AAV. J Reprod Immunol. 2013;100:20-9. doi: 10.1016/j.jri.2013.03.004.

29. Pereira N, Kucharczyk KM, Estes JL, Gerber RS, Lekovich JP, Elias RT, et al. Human papillomavirus infection, infertility, and assisted reproductive outcomes. J Pathog. 2015;2015:578423. doi: 10.1155/2015/578423.

30. Lee CA, Huang CT, King A, Chan PJ. Differential effects of human papillomavirus DNA types on p53 tumor-suppressor gene apoptosis in sperm. Gynecol Oncol. 2002;85:511-6. doi: 10.1006/gyno.2002.6662.

31. Czeglédy J, Szarka K. Detection of high-risk HPV DNA in semen and its association with the quality of semen. Int J STD AIDS. 2006;17:211-2. doi: 10.1258/095646206775809286.

32. Didelot-Rousseau MN, Diafouka F, Yayo E, Kouadio LP, Monnet D, Segondy M. HPV seminal shedding among men seeking fertility evaluation in Abidjan, Ivory Coast. J Clin Virol. 2007;39:153-5. doi: 10.1016/j.jcv.2007.03.003.

33. Çağlar GS, Garrido N. The implications of male human papilloma virus infection in couples seeking assisted reproduction technologies. J Turk Ger Gynecol Assoc. 2018;19:48-52. doi: 10.4274/jtgga.2017.0031.

34. Huang JM, Huang TH, Qiu HY, Fang XW, Zhuang TG, Liu HX, et al. Effects of hepatitis B virus infection on human sperm chromosomes. World J Gastroenterol. 2003;9:736-40. doi: 10.3748/wjg.v9.i4.736.

35. Olatunbosun O, Deneer H, Pierson R. Human papillomavirus DNA detection in sperm using polymerase chain reaction. Obstet Gynecol. 2001;97:357-60. doi: 10.1016/s00297844(00)01183-2.

36. Wang X, Zhuang J, Wu K, Xu R, Li M, Lu Y. Human semen: the biological basis of sexual behaviour to promote human papillomavirus infection and cervical cancer. Med Hypotheses. 2010;74:1015-6. doi: 10.1016/j.mehy.2010.01.009.

37. Foresta C, Pizzol D, Moretti A, Barzon L, Palù G, Garolla A. Clinical and prognostic significance of human papillomavirus DNA in the sperm or exfoliated cells of infertile patients and subjects with risk factors. Fertil Steril. 2010;94:1723-7. doi: 10.1016/j.fertnstert.2009.11.012.

38. Barbas JP, Leahy $T$, Horta AE, García-Herreros M. Sperm kinematics and subpopulational responses during the cryopreservation process in caprine ejaculates. Cryobiology. 2018;82:137-47. doi: 10.1016/j.cryobiol.2018.03.005.

39. Santiago-Moreno J, Esteso MC, Castaño C, Toledano-Díaz A, Delgadillo JA, López-Sebastián A. Seminal plasma removal by density-gradient centrifugation is superior for goat sperm preservation compared with classical sperm washing. Anim Reprod Sci. 2017;181:141-50. doi: 10.1016/j. anireprosci.2017.04.002.

40. Giles ML, Barak S, Baker G, Perna S, Tabrizi S, Greengrass V, 
et al. Outcomes from the first assisted reproduction program for HIV-serodiscordant couples in Australia. Med J Aust. 2011;195:599-601. doi: 10.5694/mja11.10156.

41. Jayaraman V, Upadhya D, Narayan PK, Adiga SK. Sperm processing by swim-up and density gradient is effective in elimination of sperm with DNA damage. J Assist Reprod Genet. 2012;29:557-63. doi: 10.1007/s10815-012-9742-x.

42. Eke AC, Oragwu C. Sperm washing to prevent HIV transmission from HIV-infected men but allowing conception in sero-discordant couples. Cochrane Database Syst Rev. 2011:CD008498. doi: 10.1002/14651858.CD008498.pub2.

43. Savasi V, Ferrazzi E, Lanzani C, Oneta M, Parrilla B, Persico T. Safety of sperm washing and ART outcome in 741 HIV-1serodiscordant couples. Hum Reprod. 2007;22:772-7. doi: 10.1093/humrep/del422.

44. Kashou AH, Sharma R, Agarwal A. Assessment of oxidative stress in sperm and semen. Methods Mol Biol. 2013;927:35161. doi: 10.1007/978-1-62703-038-0_30.

45. Aliakbari F, Sedighi Gilani MA, Yazdekhasti H, Koruji M, Asgari HR, Baazm M, et al. Effects of antioxidants, catalase and $a$-tocopherol on cell viability and oxidative stress variables in frozen-thawed mice spermatogonial stem cells. Artif Cells Nanomed Biotechnol. 2017;45:63-8. doi: 10.3109/21691401.2016.1138491.

46. Semprini AE, Levi-Setti P, Bozzo M, Ravizza M, Taglioretti A, Sulpizio $P$, et al. Insemination of HIV-negative women with processed semen of HIV-positive partners. Lancet. 1992;340:1317-9. doi: 10.1016/0140-6736(92)92495-2.

47. Foresta C, Garolla A, Parisi S, Ghezzi M, Bertoldo A, Di Nisio A, De Toni L. HPV prophylactic vaccination in males improves the clearance of semen infection. ebiomedicine. 2015;2:148793. doi: 10.1016/j.ebiom.2015.09.005.

48. Ricci G, Perticarari S, Boscolo R, Montico M, Guaschino S, Presani G. Semen preparation methods and sperm apoptosis: swim-up versus gradient-density centrifugation technique. Fertil Steril. 2009;91:632-8. doi: 10.1016/j.fertnstert.2007.11.068.

49. Younglai EV, Holt D, Brown P, Jurisicova A, Casper RF. Sperm swim-up techniques and DNA fragmentation. Hum Reprod. 2001;16:1950-3. doi: 10.1093/humrep/16.9.1950.

50. Muratori M, Tarozzi N, Cambi M, Boni L, lorio AL, Passaro C, et al. Variation of DNA fragmentation levels during density gradient sperm selection for assisted reproduction techniques: a possible new male predictive parameter of pregnancy? Medicine (Baltimore). 2016;95:e3624. doi: 10.1097/ md.0000000000003624.

51. Wan X, He X, Liu Q, Duan P, Li H. Frequent and mild scrotal heat stress impairs embryo development, implantation and offspring sex ratio in mice. Reprod Biomed Online. 2020;40:617-26. doi: 10.1016/j.rbmo.2020.01.020.

52. Kim LU, Johnson MR, Barton S, Nelson MR, Sontag G, Smith $J R$, et al. Evaluation of sperm washing as a potential method of reducing HIV transmission in HIV-discordant couples wishing to have children. AIDS. 1999;13:645-51. doi: 10.1097/00002030-199904160-00004.

53. Sauer MV. Sperm washing techniques address the fertility needs of HIV-seropositive men: a clinical review. Reprod Biomed Online. 2005;10:135-40. doi: 10.1016/s14726483(10)60815-2.

54. Cakar Z, Cetinkaya B, Aras D, Koca B, Ozkavukcu S, Kaplanoglu $\dot{I}$, et al. Does combining magnetic-activated cell sorting with density gradient or swim-up improve sperm selection? J Assist Reprod Genet. 2016;33:1059-65. doi: 10.1007/s10815-0160742-0.
55. Siegel MO, Borkowska AG, Dubrovsky L, Roth M, Welti $R$, Roberts $A D$, et al. HIV infection induces structural and functional changes in high density lipoproteins. Atherosclerosis. 2015;243:19-29. doi: 10.1016/j.atherosclerosis.2015.08.036.

56. Nicopoullos JD, Frodsham LC, Ramsay JW, Almeida PA, Rozis G, Gilling-Smith C. Synchronous sperm retrieval and sperm washing in an intracytoplasmic sperm injection cycle in an azoospermic man who was positive for human immunodeficiency virus. Fertil Steril. 2004;81:670-4. doi: 10.1016/j.fertnstert.2003.08.019.

57. Bujan L, Daudin M, Moinard N, Plante P, Parinaud J, Pasquier C. Azoospermic HIV-1 infected patients wishing to have children: proposed strategy to reduce HIV-1 transmission risk during sperm retrieval and intracytoplasmic sperm injection: case report. Hum Reprod. 2007;22:2377-81. doi: 10.1093/ humrep/dem175.

58. Nicopoullos JD, Almeida P, Vourliotis M, Gilling-Smith C. A decade of the sperm-washing programme: correlation between markers of HIV and seminal parameters. HIV Med. 2011;12:195-201. doi: 10.1111/j.1468-1293.2010.00868.x.

59. Tomari H, Honjo K, Nagata Y. Evaluation of a new sperm density gradient and sperm wash for assisted reproductive technology. Fertil Steril. 2017;108:e243. doi: 10.1016/j. fertnstert.2017.07.731.

60. Inoue $\mathrm{O}$, Kuji $\mathrm{N}$, Ito $\mathrm{H}$, Yamada $\mathrm{M}$, Hamatani T, Oyadomari $\mathrm{A}$, et al. Clinical efficacy of a combination of Percoll continuous density gradient and swim-up techniques for semen processing in HIV-1 serodiscordant couples. Asian J Androl. 2017;19:20813. doi: 10.4103/1008-682x.173442.

61. Zamora MJ, Obradors A, Woodward B, Vernaeve V, Vassena $R$. Semen residual viral load and reproductive outcomes in HIV-infected men undergoing ICSI after extended semen preparation. Reprod Biomed Online. 2016;32:584-90. doi: 10.1016/j.rbmo.2016.02.014

62. Bujan L, Pasquier C. People living with HIV and procreation: 30 years of progress from prohibition to freedom? Hum Reprod. 2016;31:918-25. doi: 10.1093/humrep/dew036.

63. Nuovo GJ, Becker J, Simsir A, Margiotta M, Khalife G, Shevchuk M. HIV-1 nucleic acids localize to the spermatogonia and their progeny. A study by polymerase chain reaction in situ hybridization. Am J Pathol. 1994;144:1142-8.

64. Vo KT, Montgomery ME, Mitchell ST, Scheerlinck PH, Colby DK, Meier KH, et al. Amanita phalloides Mushroom Poisonings - Northern California, December 2016. MMWR Morb Mortal Wkly Rep. 2017;66:549-53. doi: 10.15585/mmwr.mm6621a1.

65. Pudney J, Nguyen H, Xu C, Anderson DJ. Microscopic evidence against HIV-1 infection of germ cells or attachment to sperm. J Reprod Immunol. 1999;44:57-77. doi: 10.1016/ s0165-0378(99)00020-0.

66. Bujan L, Pasquier C, Labeyrie E, Lanusse-Crousse P, Morucci M, Daudin M. Insemination with isolated and virologically tested spermatozoa is a safe way for human immunodeficiency type 1 virus-serodiscordant couples with an infected male partner to have a child. Fertility and sterility. 2004;82:857-62. doi: 10.1016/j.fertnstert.2004.02.128.

67. Bourlet T, Levy R, Maertens A, Tardy JC, Grattard F, Cordonier H, Laurent JL, Guerin JF, Pozzetto B. Detection and characterization of hepatitis C virus RNA in seminal plasma and spermatozoon fractions of semen from patients attempting medically assisted conception. Journal of clinical microbiology. 2002;40:3252-5. doi: 10.1128/JCM.40.9.32523255.2002.

68. Ohl J, Partisani M, Wittemer C, Schmitt MP, Cranz C, Stoll- 
Keller F, Rongieres C, Bettahar-Lebugle K, Lang JM, Nisand I. Assisted reproduction techniques for HIV serodiscordant couples: 18 months of experience. Human Reprod. 2003;18:1244-9. doi: 10.1093/humrep/deg258.

69. Halfon P, Giorgetti C, Bourliere M, Chabert-Orsoni V, Khiri $H$, Penaranda $G$, et al. Medically assisted procreation and transmission of hepatitis C virus: absence of HCV RNA in purified sperm fraction in HIV co-infected patients. AIDS. 2006;20(2):241-6. doi: 10.1097/01 aids.0000200532.56490.

70. Bostan A, Vannin AS, Emiliani S, Debaisieux L, Liesnard C,
Englert Y. Development and evaluation of single sperm washing for risk reduction in artificial reproductive technology (ART) for extreme oligospermic HIV positive patients. Current HIV research. 2008;6:461-5. doi: 10.2174/157016208785861168.

71. Lambert-Niclot S, Tubiana R, Beaudoux C, Lefebvre G, Caby $\mathrm{F}$, Bonmarchand $\mathrm{M}$, et al. Detection of HIV-1 RNA in seminal plasma samples from treated patients with undetectable HIV-1 RNA in blood plasma on a 2002-2011 survey. AIDS. 2012;26:971-5. doi: 10.1097/QAD.0b013e328352ae09. 